\title{
Ayçiçeğinde Yağ Verimi ve Bazı Verim Öğeleri Arasında Illişkilerin Belirlenmesi
}

\author{
Yalçın KAYA ${ }^{1} \quad$ Göksel EVCi1 1 Veli PEKCAN ${ }^{1} \quad$ Tahir GÜCER $^{1} \quad$ M. İbrahim YILMAZ1 \\ Geliş Tarihi: 13.04.2009 \\ Kabul Tarihi: 22.12.2009
}

\begin{abstract}
Öz: Araştırma; ayçiçeğinde yağ veriminin oluşumunda belirleyici rol oynayan verim öğeleri arasındaki ilişkileri, regresyon ve korelasyon analiziyle belirlemek amacıyla, Edirne koşullarında 2000-2007 yılları arasında kuru şartlarda kurulan verim denemelerindeki veriler kullanılarak yapılmıştır. Çalışmada, Trakya Tarımsal Araştırma Enstitüsü'nce yürütülen Ülkesel Ayçiçeği Islahı Projesinde, en çok tester olarak kullanılan 0536-R restorer hattıyla yapılan hibritler yer almıştır. Yapılan korelasyon analizlerinde, yağ verimi ve fizyolojik olgunluk süresi hariç, diğer verim öğeleri arasında önemli ilişkiler belirlenmiştir. Yapılan regresyon analizleri sonucunda, yağ verimi ve diğer tüm verim öğeleri arasında yine önemli ilişkiler bulunmuş olup, en yüksek katsayı, beklenildiği gibi, tane verimiyle olmuş ve bu öğeyi bitki boyu, 1000 tane ağırlığı ve tabla çapı izlemiştir. Yağ veriminin oluşumunda, yağ oranına nazaran tane verimi daha belirleyici rol oynarken, tane verimi ve bitki boyunda lineer, diğerlerinde kuadratik ilişkiler belirlenmiştir. Tabla çapı ve 1000 tane ağırlığıyla olan ilişkide ise, yine lineere yakın kuadratik bir ilişkinin olduğu tespit edilmiştir. Yapılan regresyon analizleri sonucu ortaya çıkan sonuçlara göre, $70 \mathrm{~g}$ dan fazla bin tane ağırlığı, \% 53'den fazla yağ oranı ve $24 \mathrm{~cm}$ den fazla tabla çapı istenildiğinde, yağ veriminden taviz verilmesi gerektiği bulunmuştur. Fenolojik açıdan ise, çiçeklenmede 73 , fizyolojik olgunlukta 105 ve tane doldurma döneminde 45 günden sonra, yağ verimindeki artışlar yerini düşüşlere bırakmıştır.
\end{abstract}

Anahtar Kelimeler: Ayçiçeği, Hibrit, Yağ verimi, Verim öğeleri, Regresyon analizi

\section{The Determination Relationships Between Oil Yield and Some Yield Traits in Sunflower}

\begin{abstract}
A study was conducted to determine the relationships between oil yield and some important yield traits in sunflower with regression and correlation analysis. This study was performed on data of experiments conducted in Edirne under dryland conditions during 2000-2007. The hybrids used in the experiments were obtained by crossing with $0536-\mathrm{R}$ restorer line. This line has been used as tester mostly in National Sunflower Breeding Project conducted by Trakya Agricultural Research Institute. Based on correlations analysis, significant relationships were observed between oil yield and other yield traits except physiological maturity. Regression analysis revealed significant relationships between oil yield and yield traits. The highest regression coefficients were calculated with seed yield, plant height, 1000 seed weight and head diameter. Seed yield played more important role for oil yield than oil content of seed. The linear relationships between oil yield and seed yield or plant height, and the quadratic relationships for other traits were observed. Results indicated that over $70 \mathrm{~g}$ seed weight per thousand, $53 \%$ oil content and $24 \mathrm{~cm}$ head diameter are tended to reduce oil yield of sunflower hybrids. Additionally, regression analysis also showed that oil yield started to decline after 73 day on flowering, 105 day at physiological maturity and 45 day at seed filling periods.
\end{abstract}

Key Words: Sunflower, Hybrid, Oil Yield, Yield traits, Regression analysis.

\section{Giriş}

Ayçiçeği ülkemizin en önemli yağ bitkisi olup, geniş bir adaptasyon kabiliyeti olması ve ekimden hasada, fazla bir işgücü gerektirmemesi nedeniyle, başta Trakya-Marmara bölgesi olmak üzere, birçok bölgede ekilmektedir. Ülkemizde genelde kurak şartlarda ve yazın yetiştirildiğinden, yazın hüküm süren olumsuz iklim koşulları, ayçiçeği verimini önemli ölçüde etkilemektedir. Son yıllarda bu dönemdeki yağışların düzensiz olması, özellikle süt olum devresindeki aşırı sıcaklar, tane veriminin yanında, yağ oranını düşürüp kabuk oranını arttırarak, birim alandan alınan yağ verimini de önemli ölçüde azaltmaktadır.

Ülkemizde ayçiçeği çerezlik de tüketilmesine rağmen, büyük oranda yağlık olarak yetiştirilmektedir. Çerezlik ekim alanları Doğu ve İç Anadolu'da 

ilişkilerin belirlenmesi"

yoğunlaşırken, yağlık tip ayçiçeğinin \% 70 den fazlası, Trakya Bölgesinde ekilmektedir. Diğer ekim alanları ise, Güney Marmara, Karadeniz, Çukurova, İç Anadolu ve Ege bölgesinde yer almaktadır (Kaya ve ark. 2008b). Ülkemizde yağlık tip ayçiçeği, yağ üretmek için yetiştirilmesine rağmen, son yıllara kadar yağ oranına göre bir alım olmadığından, doğal olarak üreticiler de, genelde tane verimi yüksek çeşitleri tercih etmektedir.

Bu durum, ayçiçeğinin ülkemizde en fazla ekilen yağ bitkisi olması nedeniyle, 2008 yılında bitkisel yağ açığının, 2 milyar \$ a ulaşmasında önemli etkenlerden biridir (Anonim 2009). Ancak, 2008 yılından itibaren, ülkemizde yağlık tip ayçiçeğinin \% 30-40 oranında alımını gerçekleştiren Trakya Birliğin, yağ oranına göre alımlara başlaması, üreticilerin bu yıldan itibaren, kısa sürede yağ oranı ve dolayısıyla yağ verimi yüksek çeşitlere yönelmesini sağlayacaktır.

Ülkemizde ayçiçeği üretiminde genelde hibrit tohumluklar kullanılmakta olup, hibrit çeşitler, yüksek verim performansı, üstün kalite özellikleri, homojen görünümü, bazı hastalıklara ve orobanşa dayanıklı olmaları nedeniyle, üreticilerce tercih edilmektedir. Bu nedenle ülkemizde ve dünyada ayçiçeğinde ıslah programları genelde, hibrit ıslahına yöneliktir. Bu ıslah programlarında hedef, yüksek tane verimi ve yağ oranı, dolayısıyla yüksek yağ verimi, erkencilik, hastalık ve zararlılara dayanıklılı vb. özelliklere sahip kendilenmiş hatlar geliştirilip, bunlarla melez azmanlığından yararlanılarak arzulanan performansa sahip hibritler elde etmektir. Ancak Islah edilen bu hatların, değişik çevre koşullarında üstün performanslarını sürdürebilmesi de son derece önemlidir. Bu nedenle, bir yağ bitkisi olan ayçiçeğinde, ayçiçeği ıslahçılarına, yağ verimine etki eden faktörlerin, belirleyici rol oynayan verim öğelerinin ve aralarındaki ilişkilerinin bilinmesi, istenilen hedeflere ulaşmada büyük fayda sağlayacaktır.

Ayçiçeğinde yağ verimi, çevre koşullarından çok fazla etkilenen tane verimi ve genetik katkının fazla olduğu yağ oranı tarafından belirlenmektedir. Tane veriminin oluşumunda, önemli verim öğelerinin etkis ve aralarındaki etkileşimler, korelasyon ve path analizi (Alvarez ve ark. 1992, Badwal ve ark. 1993, Dağüstü 2002, Kaya ve Atakisi 2003, Parameswari ve ark. 2004, Joksimovic ve ark. 2004, Hladni ve ark. 2006 , Rondanini ve ark. 2007, Gontcharov ve Zaharova 2008, Kaya ve ark. 2008a), kombinasyon kabiliyeti analizleri (Ashok ve ark. 2000, Marinković ve ark. 2000 , Skoric ve ark. 2000, Kaya ve Atakisi 2004, Kaya 2005, Farrokhi ve ark. 2008, Hladni ve ark. 2008) birçok araştırmacı tarafından incelenmiştir. Ancak regresyon analiziyle bu ilişkilerin aşamalarını ortaya koyan çalışmalar oldukça az olup, Kaya ve ark. (2005a ve b, 2006, 2007a ve b), Edirne koşullarında tane verimiyle diğer verim öğelerinin ilişkisini araştırmışlardır. Ancak ayçiçeğinde, direk yağ verimine etki eden faktörleri ve düzeylerini belirlemeye yönelik bir araştırma bugüne kadar yapılmamıştır.

Araştırmanın amacı, ülkemizin ayçiçeğinde en fazla ekim alanı ve üretime sahip illerinden biri olan Edirne'de uzun yılları kapsayan farklı iklim koşullarında, incelenen verim öğelerinin, regresyon analizinden yararlanarak, yağ veriminin oluşumundaki rollerini ve ne düzeyde etkili olduğunu belirlemektir.

\section{Materyal ve Yöntem}

Araştırmada, 2000 - 2007 yılları arasında Edirne koşullarında, Trakya Tarımsal Araştırma Enstitüsü'nce yürütülen Ülkesel Ayçiçeği Islah projesinde, halen fazla miktarda tester olarak kullanılan 0536-R restorer hattının kullanıldığı, değişik ana ebeveyn hatlarıyla yapılan hibritler yer almıştır. 0536-R hattı, ülkemizde 1999 yılında tescil edilen ve halen üretilen TARSAN1018 ayçiçeği hibritinin baba hattıdır. Bu hat, yüksek tane ve yağ verimi performansının yanında, orobanşın yeni ırklarına oldukça toleranslı ve stabil olup, değişik iklim ve toprak koşullarında da üstün performans gösteren hibritler oluşturmaktadır.

Yağ veriminin 8 farklı yılda değişik iklim koşullarında, aynı çeşidin kullanılmasıyla genetik faktör dikkate alınmaksızın, değişik verim öğeleri ile ilişkisi, korelasyon analizi yapılarak incelenmiş, bu ilişkinin dereceleri ve aşamaları regresyon analizi yapılarak belirlenmiştir. Yapılan regresyon ve korelasyon analizlerinde, JMP 7 ve Minitab istatistik paketi kullanılmıştır. Araştırmada, ayçiçeğinde yağ verimine etki eden esas faktörleri belirlemek, ilişkinin durumlarını ve seviyelerini ayrı ayrı incelemek amacıyla, her yıl denemelerde 0536-R hat ile yapılan hibritlere ait veriler kullanılmıştır.

Projede kurulan toplam 84 adet denemede, 2000 yılında 9, 2001'de 10, 2002'de 13, 2003'de 8 ve 2004 'de 13, 2005'de 11, 2006'de 12 ve 2007'de 8 denemede, 0536-R yapılan toplam 192 adet ayçiçeği hibriti yer almıştır. Verim denemeleri, Enstitü arazisinde kurak şartlarda 3 tekerrürlü olarak, Tesadüf blokları deneme desenine göre kurulmus olup, 3 sıra ekilen çeşitlerin, orta tek sırası hasat edilmiştir. Yine bu sıranın ilk bitkileri de kenar tesiri nedeniyle hasat edilmeyerek, değerlendirme dışı bırakılmıştır. Hibritler $70 \times 35 \mathrm{~cm}$ ekim sıklığında ve $6 \mathrm{~m}$ uzunluğunda ekilmiş olup, parsel büyüklüğü hasatta, $3.78 \mathrm{~m}^{2} \mathrm{dir}$ 
Ekimler genelde Nisan ayı içerisinde yapılmış olup, Ağustos sonu - Eylül başında hasat edilmiştir. Çıkış garantisini sağlamak amacıyla ekimde, açılan çukurlara elle 3-4 tohum atılmış ve daha sonra elle tekleme (seyreltme) yapılmıştır. Ekim zamanında $25 \mathrm{~kg}$ 20-20-0 kompoze gübre kullanılmış olup, üst gübreleme yapılmamıştır. Denemelerde yabancı of kontrolü; ekim öncesi Trifluarin terkipli ilaç uygulanarak ve daha sonra da bitkiler $15-20 \mathrm{~cm}$ boyunda sıra aras çapa makinesiyle, sıra üzeri de, elle çapalanarak yapılmıştır.

Edirne Trakya Tarımsal Araştırma arazisi, 410 40' kuzey enlemi ve 26을 $34^{\prime}$ doğu boylamında olup, deniz seviyesinden yüksekliği $41 \mathrm{~m}$ dir. Denemelerin kurulduğu tarlalar, kumlu-killi-tınlı toprak yapısına sahip olup, $\mathrm{PH}$ 6,5 tur. Topraktaki bitkiye yarayışlı Fosfor $\left(\mathrm{P}_{2} \mathrm{O}_{5}\right)$ yaklaşık $22 \mathrm{~kg} / \mathrm{da}$, Potasyum $\left(\mathrm{K}_{2} \mathrm{O}\right)$ miktarı 65 $\mathrm{kg} / \mathrm{da}$ olup, organik madde ise \% 1-2 civarındadır. Edirne ilindeki araştırma yıllarındaki ayçiçeği sezonuna ait meteorolojik veriler, Çizelge 1 de verilmiştir.

Araştırmada, ayçiçeğinde en önemli verim öğeleri olan yağ ve tane verimi $\mathrm{kg} / \mathrm{da}$ ), yağ oranı (\%), 1000 tane ağırlığı (g), çiçeklenme, fizyolojik olgunluk ve tane doldurma süreleri (gün), bitki boyu $(\mathrm{cm})$ ve tabla çapı (cm) ölçülmüştür. Ayçiçeğinde yağ ve tane veriminin oluşumunda en önemli dönem olması nedeniyle, tane doldurma periyodu da, çiçeklenme başlangıcından fizyolojik olgunluk zamanına kadar olan süre olarak, araştırmada yer almıştır.

\section{Bulgular ve Tartışma}

Araştırmada yer alan 192 adet ayçiçeği hibritinin yağ verimi ortalaması ise, $108,5 \mathrm{~kg} / \mathrm{da}$ olarak hesaplanmış olup (medyan, 105,5 kg/da), standart sapması $33,7 \mathrm{~kg} / \mathrm{da}$ 'dır. Hibritlerin yağ verim değerleri 30,2 ile 195,6 kg/da arasında gözlemlenmiştir.

Yapılan korelasyon analizlerinde, yağ verimi ve diğer verim öğeleri arasında fizyolojik olgunluk süresi hariç, istatistiki açıdan önemli ilişkiler gözlemlenmiştir (Çizelge 2). Çiçeklenme süresi ile yağ verimi arasında negatif bir ilişki söz konusu iken, diğer verim öğeleri arasında, pozitif ve oldukça yüksek oranda bir ilişkiler mevcuttur.

Araştırmada, birbirini tamamlayıcı öğeler olan yağ verimi ve tane verimi $(0,980)$, çiçeklenme ve fizyolojik olgunluk süresi $(0,754)$ hariç, en yüksek korelasyon katsayısı, bitki boyu ve tane verimi arasında hesaplanırken $(0,721)$, bunu yine bitki boyu ve yağ verimi $(0,678)$ ve 1000 tane ağırlığı ve tane verimi $(0,644)$ takip etmiştir.

Araştırmada çiçeklenmeyle diğer verim öğeleri arasında, belirleyici olduğu fenolojik gözlemler hariç, istatistikî açıdan önemli ve negatif yönde ilişkiler dikkat çekmektedir. Bu durum, daha önce de aynı yerde yapılan araştırmalarda görüldüğü gibi (Kaya ve ark. 2005a ve b, 2006, 2007a ve b), Edirne ilinde çeşitlerin yüksek verim için mutlaka erkenci olması gerektiğini, bir daha teyit etmektedir. Zaten erkenci bir baba hattı olan ve erkenci hibritler oluşturan bu hattaki oluşan bu sonuç, uygulanan ıslah programında, yüksek tane ve yağ verimi ve diğer kalite özelliklerine sahip hat geliştirmek için yapılacak bir seleksiyonun, erkenciliğe yönelik olmasını ortaya koymaktadır. Buna karşılık, fizyolojik olgunluk süresinin genelde gerek yağ verimi, gerekse diğer verim öğeleriyle önemsiz bir ilişkisinin olması, ayçiçeğinde fenolojik açıdan çiçeklenmenin daha belirleyici rol oynadığını göstermektedir.

Bunun yanında ayçiçeğinde tane ve yağ veriminin oluşumunda en önemli devre olan tane doldurma periyodunun da, hem yağ verimiyle, hem de diğer verim öğeleriyle önemli ve pozitif yönde olan ilişkileri, fenolojik gözlemler açısından önemli bir öğe olduğu ortaya çıkmaktadır. Yine Gontcharov ve Zaharova (2008) yaptığı araştırmada, ayçiçeğinde tane verimi, çiçeklenmeye kadar olan devrede, yağ oranının tane doldurma periyodu sırasında ve yağ veriminin ise, çıkıştan fizyolojik olgunluğa kadar olan tüm yetişme süresi boyunca belirlendiğini vurgulayarak, erkenci çeşitlerin de yüksek verim performansına sahip olabileceğini belirtmişlerdir.

Çizelge 1: Denemelerin yürütüldüğü Edirne ilinde ayçiçeği yetişme dönemine ait iklim değerleri

\begin{tabular}{|c|c|c|c|c|c|c|c|c|c|c|c|c|c|c|c|c|c|c|}
\hline \multirow[b]{2}{*}{ Yıllar } & \multicolumn{3}{|c|}{ Nisan } & \multicolumn{3}{|c|}{ Mayıs } & \multicolumn{3}{|c|}{ Haziran } & \multicolumn{3}{|c|}{ Temmuz } & \multicolumn{3}{|c|}{ Ağustos } & \multicolumn{3}{|c|}{ Eylül } \\
\hline & NN & OS & TY & NN & OS & TY & $\mathrm{NN}$ & OS & TY & NN & OS & TY & NN & OS & TY & $\mathrm{NN}$ & OS & TY \\
\hline 2000 & 68.7 & 15.5 & 60.9 & 62.6 & 18.4 & 52.6 & 54.4 & 22.7 & 16.7 & 45.5 & 26.8 & 0.8 & 51.6 & 25.2 & 30.5 & 64.0 & 19.7 & 42.0 \\
\hline 2001 & 69.6 & 13.0 & 57.7 & 7.9 & 18.3 & 25.8 & 58.2 & 22.6 & 16.7 & 0.1 & 27.3 & 28.7 & 9.3 & 26.5 & & 0.2 & 21.2 & 62.2 \\
\hline 2002 & 66.9 & 11.7 & 30.3 & 56.4 & 18.4 & 15.9 & 56.7 & 23.4 & 26.2 & 55.2 & 26.7 & 33.9 & 60.2 & 24.2 & 12.8 & 67.2 & 19.8 & 118.9 \\
\hline 2003 & 62.5 & 10.4 & 55.1 & 58.4 & 20.2 & 79.8 & 51.9 & 24.7 & 5.2 & 53.8 & 25.3 & 44.8 & 52.2 & 26.3 & 13.4 & 60.5 & 19.1 & 24.5 \\
\hline 2004 & 59.8 & 13.2 & 14.6 & 62.8 & 17.1 & 59.6 & 68.8 & 22.0 & 95.2 & 59.0 & 24.5 & 34.1 & 61.9 & 24.0 & 25.1 & 62.4 & 20.6 & 0.5 \\
\hline 2005 & 62.2 & 13.4 & 17.6 & 67.7 & 18.5 & 55.4 & 61.8 & 21.5 & 15.1 & 65.9 & 24.4 & 106.9 & 62.5 & 24.8 & 48.4 & 66.8 & 20.1 & 49.5 \\
\hline 2006 & 65.7 & 13.9 & 24.0 & 63.7 & 18.3 & 36.5 & 64.3 & 22.3 & 87.8 & 60.6 & 23.8 & 62.1 & 57.1 & 26.2 & 40.9 & 68.3 & 19.8 & 86.0 \\
\hline 2007 & 59.3 & 12.5 & 23.7 & 67.4 & 19.5 & 122.4 & 56.0 & 24.8 & 8.2 & 42.9 & 27.0 & 0.8 & 52.1 & 26.2 & 9.1 & 63.0 & 19.4 & 45.7 \\
\hline
\end{tabular}

NN: Nispi Nem (\%), OS: Ortalama Sıcaklık ( $\left.{ }^{\circ} \mathrm{C}\right)$, TY: Toplam Yağış (mm) 

ilişkilerin belirlenmesi"

Çizelge 2: Araştırmada yer alan verim öğeleri arasındaki korelasyon (K. K.) ve P değerleri $(P)$

\begin{tabular}{|c|c|c|c|c|c|c|c|c|c|c|c|c|c|c|c|c|c|}
\hline & \multicolumn{2}{|c|}{$\begin{array}{c}\text { Tane } \\
\text { Verimi (TV) }\end{array}$} & \multicolumn{2}{|c|}{$\begin{array}{c}\text { Yağ } \\
\text { Oranı (YO) }\end{array}$} & \multicolumn{2}{|c|}{$\begin{array}{c}\text { Yağ } \\
\text { Verimi (YV) }\end{array}$} & \multicolumn{2}{|c|}{$\begin{array}{c}\text { 1000 Tane } \\
\text { Ağırlığı } \\
\text { (BTA) }\end{array}$} & \multicolumn{2}{|c|}{$\begin{array}{l}\text { Çiçeklenme } \\
\text { (ÇD) }\end{array}$} & \multicolumn{2}{|c|}{$\begin{array}{c}\text { Fizyolojik } \\
\text { Olgunluk } \\
\text { (FO) }\end{array}$} & \multicolumn{2}{|c|}{$\begin{array}{c}\text { Tane } \\
\text { Doldurma (TD) }\end{array}$} & \multicolumn{2}{|c|}{$\begin{array}{c}\text { Bitki } \\
\text { Boyu (BB) }\end{array}$} & \multirow{2}{*}{$\begin{array}{l}\text { Tabla } \\
\text { Çapı } \\
\text { (TÇ) } \\
\text { K. K. }\end{array}$} \\
\hline & K. K. & $P$ & K. K. & $P$ & K. K. & $\mathbf{P}$ & K. K. & $P$ & K. K. & $P$ & K. K. & $P$ & K. K. & $\mathbf{P}$ & K. K. & $P$ & \\
\hline T V & 1,000 & - & & & & & & & & & & & & & & & \\
\hline Yo & 0,189 & 0,009 & 1,000 & - & & & & & & & & & & & & & \\
\hline YV & 0,980 & 0,000 & 0,374 & 0,000 & 1,000 & - & & & & & & & & & & & \\
\hline BTA & 0,644 & 0,000 & 0,089 & 0,219 & 0,618 & 0,000 & 1,000 & - & & & & & & & & & \\
\hline ÇD & $-0,270$ & 0,000 & $-0,232$ & 0,001 & $-0,298$ & 0,000 & $-0,169$ & 0,019 & 1,000 & - & & & & & & & \\
\hline FO & $-0,081$ & 0,266 & 0,038 & 0,602 & $-0,069$ & 0,340 & 0,107 & 0,140 & 0,754 & 0,000 & 1,000 & - & & & & & \\
\hline TD & 0,213 & 0,003 & 0,345 & 0,000 & 0,265 & 0,000 & 0,372 & 0,000 & $-0,100$ & 0,168 & 0,578 & 0,000 & 1,000 & - & & & \\
\hline BB & 0,721 & 0,000 & 0,006 & 0,937 & 0,678 & 0,000 & 0,581 & 0,000 & $-0,164$ & 0,023 & $3-0,075$ & 0,299 & 0,089 & 0,218 & 1,000 & - & \\
\hline TÇ & 0,573 & 0,000 & 0,040 & 0,586 & 0,544 & 0,000 & 0,461 & 0,000 & $-0,330$ & 0,000 & $-0,151$ & 0,037 & 0,182 & 0,012 & $0,517^{*} \mathrm{C}$ & 0,000 & 1,000 \\
\hline
\end{tabular}

Gerek bölgede, gerekse diğer ülkelerde daha önce yapılan araştırmalarda (Dagustu 2002, Kaya ve Atakisi 2003, Kaya ve ark. 2003, Hladni ve ark. 2004, Dusanic ve ark. 2004, Kaya ve ark. 2005a, Farrokhi ve ark. 2008), en önemli verim öğeleri arasında yer alan bitki boyunda, fenolojik gözlemler ve yağ oranı hariç, 0536-R hattının genelde kısa boylu hibritler vermesine rağmen, diğer verim öğeleriyle oldukça yüksek seviyede pozitif yönde ilişkiler ortaya çıkmıştır.

Daha önce yapılan birçok araştırmada, hem tane ve yağ verimi, hem de diğer verim öğeleriyle, pozitif yönde önemli ilişkiler ortaya koyan 1000 tane ağırlığ da (Kaya ve Atakisi 2003, Kaya ve ark. 2008a), yağ oranı ve çiçeklenme süresi haricinde, diğer verim öğeleriyle oldukça yüksek ve istatistiki açıdan önemli korelasyon katsayılarına sahip olmuştur.

Araştırmada, ayçiçeğinde yağ veriminde etkili verim öğelerinin, katkı düzeylerini, aşamalarını ve yönünü ortaya koymak amacıyla yapılan regresyon analizinde elde edilen tüm regresyon değerleri istatistikî olarak önemli bulunmuştur (Çizelge 3). En yüksek regresyon katsayısı beklenildiği gibi, yağ verimini oluşturan öğelerden biri olan tane verimiyle belirlenirken, diğer tamamlayıcı öğe olan yağ oranının regresyon katsayısı, fizyolojik olgunlaşma süresinden sonra en düşük değer olarak hesaplanmıştır. Bu durum, yağ veriminin oluşumunda, tane veriminin yağ oranına göre daha belirleyici rol oynadığını göstermektedir. Yine korelâsyon analizinde de benzer sonuçların ortaya çıkması, önceki araştırmalarda da aynı sonuçların elde edilmesi (Alvarez ve ark. 1992, Badwal ve ark. 1993, Kaya ve Atakisi 2003) bu kanıyı pekiştirmektedir. Diğer yandan, yüksek regresyon katsayıları açısından tane verimini, bitki boyu, 1000 tane ağırlığı ve tabla çapı takip etmiştir.
Araştırmada yer alan hibritlerin yağ oranı ortalaması \% 46,8 olup, bu oran 0536-R ile yapılan hibritlerin oldukça yüksek yağ oranına sahip olduklarını ortaya koymuştur. Yine kurak şartlarda 424,7 kg/da'a kadar tane veriminin elde edilmesi, 0536-R hattının oldukça yüksek performansının olduğunu göstermektedir (Çizelge 3). Yağ verimi ile tane verimi arasında, tane verimi arttıkça yağ veriminin de arttığını gösteren pozitif lineer bir ilişkinin olduğu görülmektedir (Şekil 1). Bu sonuçlar yağ veriminde, tane veriminin en belirleyici rol üstlendiğini ortaya koymaktadır.

Yağ oranının yağ verimiyle olan ilişkisinde ise, \% 47-48 yağ oranına kadar, pozitif yönde yağ oranı arttıkça yağ verimine olumlu katkı yapan lineere yakın bir ilişki söz konusu iken, bu orandan sonra artış hızı yavaşlamaktadır (Şekil 2). Nitekim bu artış \% 53'e kadar devam ederken, bu orandan sonra yerini düşüşe bırakmaktadır. Bu sonuç, 0536-R baba hattıyla yapılan hibritlerde, \% 53 den daha yüksek bir yağ oranı istenildiğinde, yağ veriminden taviz verilmesi gerektiğini ortaya koymaktadır. Nitekim yine bölgede daha öncede tane veriminde yapılan çalışmalarda (Kaya ve ark, 2005a, 2006, 2007a ve b) da, benzer sonuçlar elde edilmiştir.

Yağ verimin belirlenmesinde önemli rol oynayan verim öğelerinden biri olan 1000 tane ağırlığıyla olan ilişkide ise, yine 1000 tane ağırlığı arttıkça yağ veriminin de arttığı, normalde kuadratik bir yönelim göstermesine rağmen, lineere yakın bir ilişkinin olduğu ortaya çıkmıştır (Şekil 3). Ancak yağ oranında olduğu gibi, 1000 tane ağırlığında da, $70 \mathrm{~g}$ a yaklaşıldıkça, artış hızı yavaşlamakta ve daha iri taneler istendiğinde, yine yağ veriminden taviz verilmesi gerektiği görülmektedir. 
Çizelge 3: Ayçiçeğinde yağ verimi ve verim öğeleri arasındaki regresyon değerleri

\begin{tabular}{|c|c|c|c|c|c|c|c|c|c|}
\hline Verim Öğeleri & SD & Ortalama & $\begin{array}{c}\text { Standard } \\
\text { Sapma }\end{array}$ & Medyan & Minimum & Maksimum & \multicolumn{3}{|c|}{$P$ değeri } \\
\hline Yağ Oranı & 191 & 46,8 & 3,0 & 47,2 & 38,1 & 53,4 & 0,148 & 0,0001 & 16,4 \\
\hline Çiçeklenme & 191 & 72,8 & 5,5 & 71,5 & 59,0 & 86,0 & 0,200 & 0,0001 & 23,6 \\
\hline Fizyolojik Olgunluk & 191 & 108,4 & 6,7 & 107,0 & 90,0 & 127,0 & 0,141 & 0,0001 & 15,5 \\
\hline Tane Doldurma & 191 & 35,6 & 4,4 & 36,0 & 19,0 & 48,0 & 0,092 & 0,0001 & 9,5 \\
\hline
\end{tabular}

$\mathrm{R}^{2}=$ Regresyon Katsayısı, SD= Serbestlik Derecesi

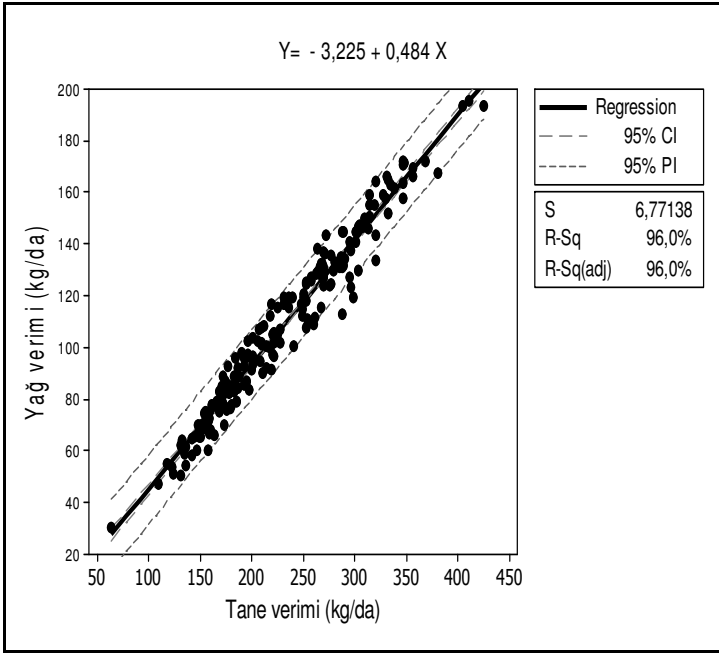

Şekil 1: Yağ verimiyle tane verimi arasındaki ilişkiler.

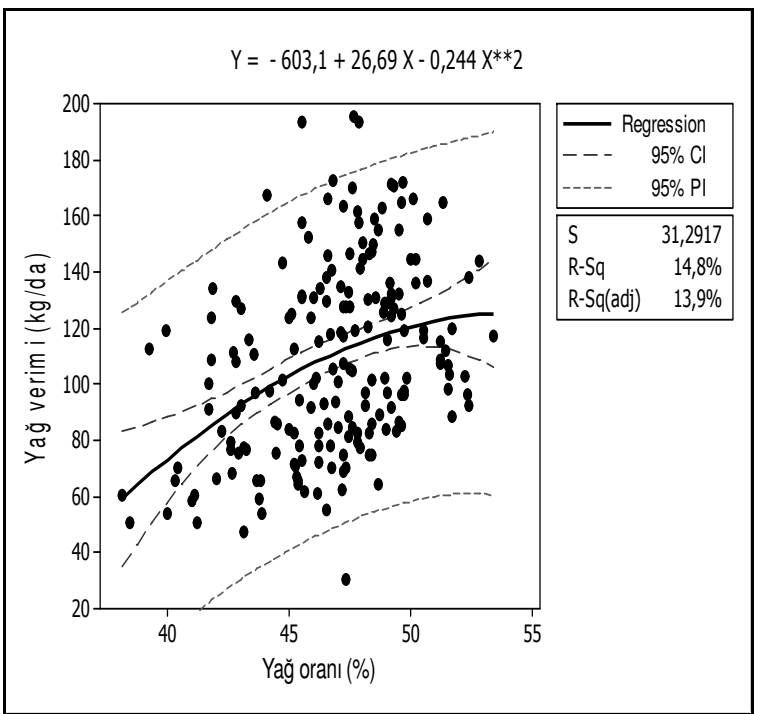

Şekil 2: Yağ verimiyle yağ oranı arasındaki ilişkiler.

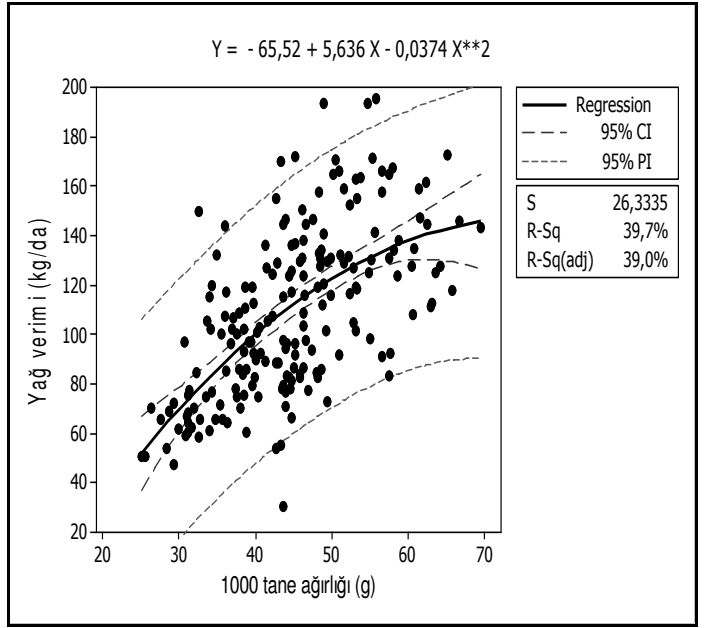

Şekil 3: Yağ verimiyle 1000 tane ağırlığı arasındaki ilişkiler.

Araştırma sonuçlarına göre en belirleyici fenolojik gözlem olan, çiçeklenme süresiyle yağ verimi arasında ise, 70 güne kadar ilk başlarda hızlı bir artış, daha sonra giderek yavaşlayan ve tamamen kuadratik bir ilişkinin söz konusu olduğu görülmektedir (Şekil 4). Bu ilişkide, mevcut artış, 73 günden sonra yerini azalışa bırakmaktadır. Bu durum, bölgede yapılan daha önceki birçok araştırmada ortaya konulan erkenci çeşitlerin daha yüksek tane ve yağ verimi verdiği, geççi çeşitlerin süt olum devresindeki aşırı sıcaklardan fazlaca etkilenmesiyle, yağ ve tane verimlerinin azaldığı sonucunu teyit etmektedir.

Araştırmada en düşük regresyon katsayısına sahip fizyolojik olgunluk süresinin yağ verimiyle olan ilişkisinde de, çiçeklenme süresine benzer kuadratik bir yönelim belirlenmiştir (Şekil 5). 105 güne kadar olan fizyolojik olgunluk süresine kadar, başlangıcında hızlı ve daha sonra yavaşlayan bir yağ verimi artışı, 110 günden sonra yerini azalmaya bırakmıştır. Beklenenin aksine araştırmada, çiçeklenme süresinde olduğu gibi, erkenci hibritler, büyük bir intimalle süt olum devrelerinde meydana gelen aşırı sıcaklardan etkilenmediklerinden, daha yüksek yağ verimlerine ulaşmışlardır. 


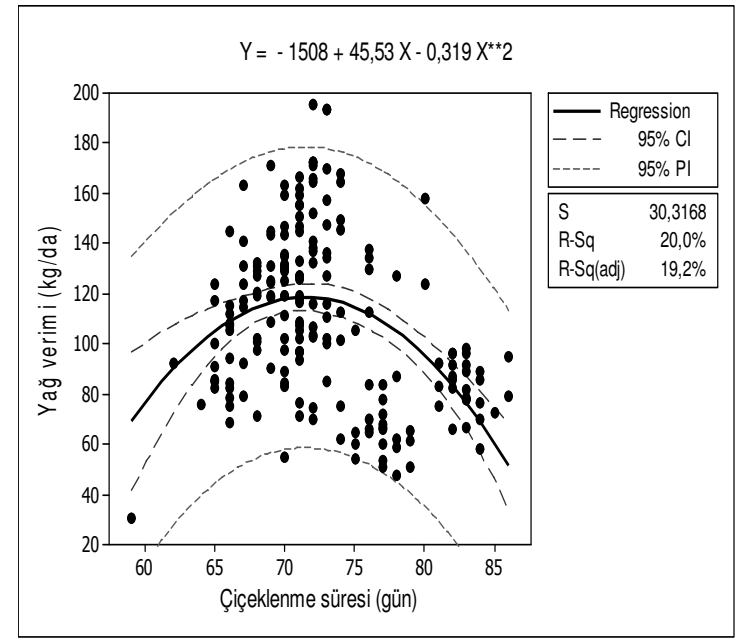

Şekil 4: Yağ verimiyle çiçeklenme süresi arasındaki ilişkiler.

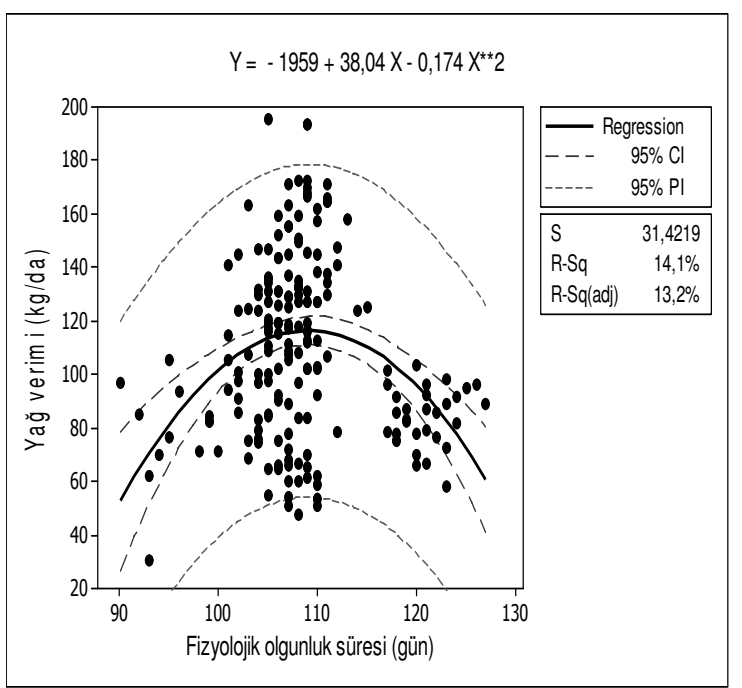

Şekil 5: Yağ verimiyle fizyolojik olgunluk süresi arasındaki ilişkiler.

Normal şartlarda, daha uzun yetişme periyoduna sahip bitkiler, daha fazla kuru madde biriktirebilme imkânına sahip olduklarından, daha yüksek verim performansı gösterebilmektedirler. Ancak özellikle ayçiçeğinde verimi belirleyici en önemli etkenlerden biri olan süt olum devresine denk gelen aşırı sıcaklar, taneler içerisindeki suyun kısa sürede buharlaşması nedeniyle, tane veriminde önemli kayıplara neden olabilmektedir (Miller ve Fick 1997, Kaya ve ark. 2005b). Buna ilaveten tanedeki suyun hızlıca kaybı, tanelerin cılız olmasına neden olarak kabuk oranını arttırmakta, dolayısıyla tane içerisindeki yağ oranını düşürerek, yağ verimini önemli ölçüde etkilemektedir. Edirne koşullarında daha önce yapılan path analizi ve diğer araştırmalarda (Kaya ve Atakişi 2003, Kaya ve ark. 2005b), gerekse diğer ülkelerde yapılan araştırmalarda (Rondanini ve ark. 2007) süt olum devresindeki bu aşırı sıcakların, tane veriminde \% 40'lara varan düşüşlere neden olduğu görülmüştür. Araştırmadaki fenolojik gözlemlerde alınan bu sonuçlar, daha önceki bu araştırma sonuçlarını teyit etmektedir.

Bunun yanında ayçiçeğinde yetişme süresinde, bitkilerin özellikle çiçeklenmeden sonra, uzun süren tane doldurma periyodunun ayçiçeğinde tane ve yağ verimini olumlu yönde etkilediği birçok araştırmada vurgulanmıştır (Miller ve Fick 1997, Kaya ve ark. 2005b). Araştırmada, 40 güne kadar olan tane doldurma süresi, ayçiçeği yağ veriminde olumlu artışlara neden olurken, büyük bir intimalle, Edirne koşullarında geççi çeşitlerin daha düşük verimlere sahip olması nedeniyle bu artış, bu noktadan sonra duraklayıp, yerini düşüşe bırakmıştır (Şekil 6).

Bir diğer önemli verim öğesi olan bitki boyu ve yağ verimi arasında ise, lineer bir ilişkinin olduğu, bitki boyu arttıkça yağ veriminin de arttığı görülmektedir (Şekil 7). Aşırı uzun boylu bitkilerdeki yatma nedeniyle, yüksek boyluluk normal şatlarda ayçiçeği tane verimini olumsuz etkilemektedir. Bu çalışmada üst noktalarda ortaya çıkması beklenen sınırlayıcı kuadratik bir eğri, 0536-R ile yapılan hibritlerin bu hattın boyunun genelde daha kısa boylu olmasından kaynaklanmış olabilir.

Birçok araştırmada en önemli verim öğeleri arasında gösterilen tabla çapı (Kaya ve Atakişi 2003, Hladni ve ark. 2006) ile yağ verimi arasında ise, araştırmada lineere yakın bir kuadratik bir ilişki belirlenmiştir (Şekil 8). Araştırmada yağ veriminin, hibritlerdeki $24 \mathrm{~cm}$ tabla çapına kadar, oldukça dikey bir artış gösterdiği gözlemlenmiştir. Nitekim araştırmada en yüksek tabla çapı $24 \mathrm{~cm}$ olup, bundan daha geniş tablalarda ise, büyük bir intimalle iri tane oluşumu nedeniyle, yağ oranının düşmesi ve tanelerin gevşekliğinin artmasıyla, dökülmelerin artarak ve tane verim kaybına neden olarak, artışın duraklayıp, daha sonra düşüş eğilimine girebileceği öngörülmektedir. 


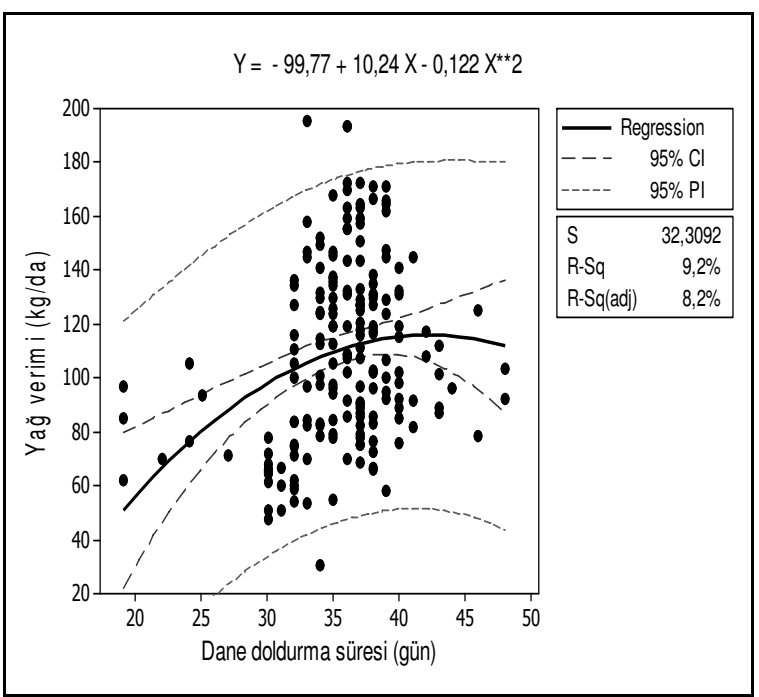

Şekil 6: Yağ verimiyle tane doldurma periyodu arasındaki ilişkiler.

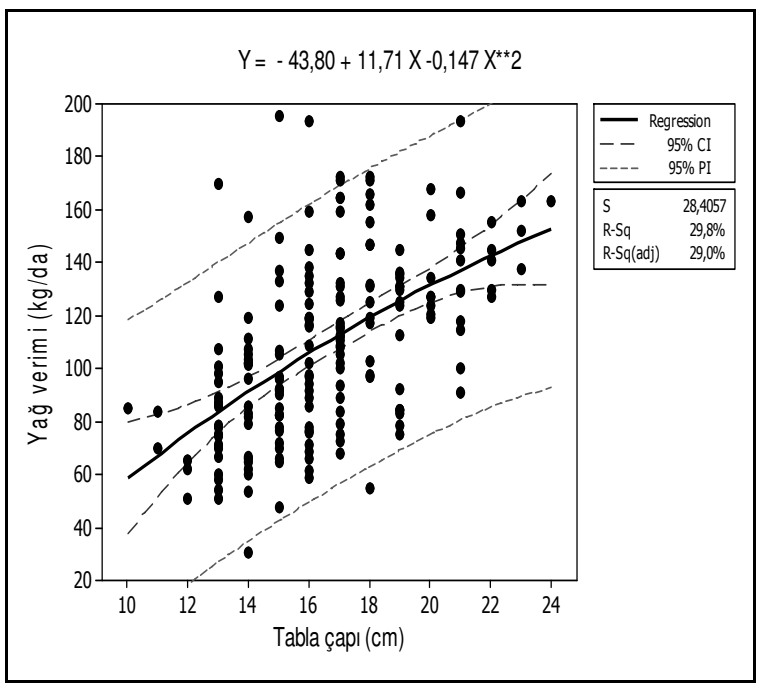

Şekil 8: Yağ verimiyle tabla çapı arasındaki ilişkiler

Fenolojik gözlemler açısından ise, araştırmada yer alan her üç öğede de, yine korelasyon analizinde olduğu gibi, regresyon analizinde de, erkenci çeşitlerde belirli bir orana kadar yağ veriminde artış söz konusu iken, geççi çeşitlerde yağ veriminde düşüşlerin olduğu görülmüştür. Nitekim çiçeklenmede 73, fizyolojik olgunlukta 105 ve tane doldurma döneminde 45 günden sonra, yağ verimindeki artış, yavaşlayıp yerini düşüşlere bırakmıştır.

Araştırmada yer alan ayçiçeğinde önemli verim öğelerinde yapılan korelasyon analizleri sonucunda, yağ verimiyle, diğer verim öğeleri arasında fizyolojik olgunluk süresi hariç, önemli ilişkiler gözlemlenmiştir.

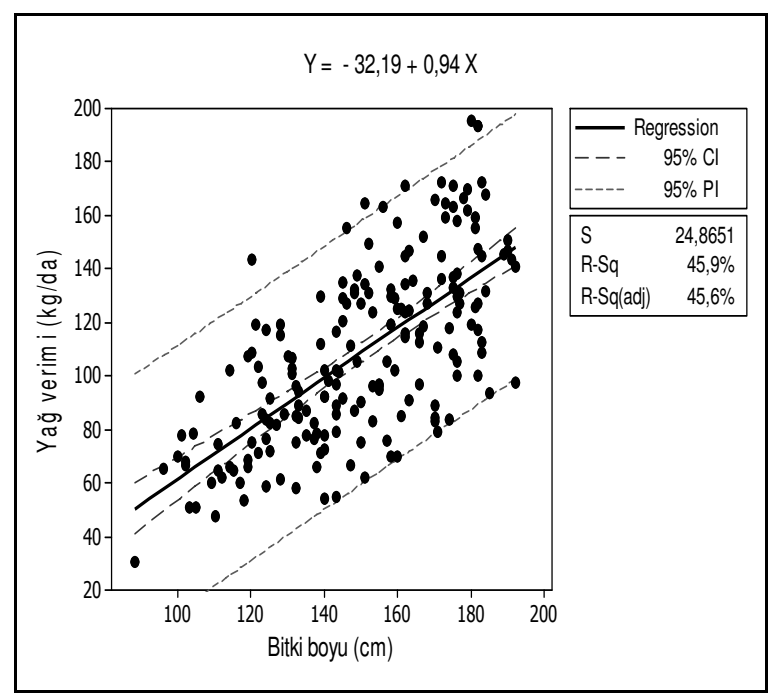

Şekil 7: Yağ verimiyle bitki boyu arasındaki ilişkiler.

Çiçeklenme ve yağ verimi arasındaki negatif yöndeki ilişki, erkenci çeşitlerin Edirne koşullarında daha fazla yağ verimine sahip olduğunu, yine çiçeklenme süresinin tane ve yağ veriminde fenolojik gözlemler açısından fizyolojik olgunluğa göre daha belirleyici rol oynadığını göstermektedir. Bu durum, Edirne koşullarında uygulanan ıslah programında, yüksek yağ verimi için yapılacak bir seleksiyonun, istenilen diğer özelliklerin yanında, erkenciliğe de yönelik olması gerektiğini, ortaya koymaktadır. Yine bitki boyu ve 1000 tane ağırlığıyla, gerek yağ verimi, gerekse diğer verim öğeleriyle pozitif yönde ve yüksek derecede önemli ilişkilerin olduğu görülmüştür

Yağ verimi ve diğer tüm verim öğeleri arasında ise, yapılan regresyon analizleri sonucunda, istatistikî açıdan önemli ilişkilerin olduğu ortaya koyulmuştur. En yüksek regresyon katsayısı beklenildiği gibi, tane verimiyle olmuş ve bu öğeyi bitki boyu, 1000 tane ağırlığı ve tabla çapı takip etmiştir. Yağ oranıyla yağ verimi regresyon katsayısının, araştırmada en düşük değerlerinden biri olarak hesaplanması, yağ veriminin oluşumunda, tane veriminin daha belirleyici rol oynadığını göstermektedir.

Yağ verimiyle tane verimi ve bitki boyu arasında, tamamen lineer bir ilişki söz konusu iken, diğer öğelerle kuadratik ilişkiler belirlenmiştir. Tabla çapı ve 1000 tane ağırlığıyla olan ilişkide ise, yine lineere yakın bir kuadratik ilişkinin olduğu tespit edilmiştir. Yapılan regresyon analizleri sonucu ortaya çıkan sonuçlar; 70 gramdan fazla iri tane, \% 53 den fazla yağ oranı ve 24 $\mathrm{cm}$ den daha fazla tabla çapı istenildiğinde, yağ veriminde taviz verilmesi gerektiğini ortaya koymuştur. 

ilişkilerin belirlenmesi"

Sonuç olarak, ülkesel ayçiçeği ıslah programında, aday ana hatların genel kombinasyon kabiliyetlerin test etmek amacıyla, en fazla tester olarak kullanılan 0536- $R$ restorer hattıla yapılan hibritlerden, uzun yıllarda, elde edilen verilerin kullanıldığı araştırmada, ayçiçeğinde yağ veriminin oluşumunda etkili faktörler ve diğer verim öğeleriyle olan ilişkileri ortaya konulmuştur. Ancak, diğer hatlar veya aynı hibritlerle benzer araştırmaların gelecekte de yapılarak, hem elde edilen sonuçlar teyit edilmiş, hem de ayçiçeğinde yağ veriminin oluşumunda etkili faktörler tam olarak ortaya konulmuş olacaktır.

\section{Kaynaklar}

Anonim 2009. TUIK 2009 yllı istatistikleri. www.turkstat.gov.tr

Alvarez, D., P. Luduena and Y. E. Frutos. 1992. Correlation and causation among sunflower traits. Proceeding of The $13^{\text {th }}$ Int. Sunflower Conf. September 7-11. 957-962. Pisa, Italy.

Ashok, S., N. Mohamed Sheriff, S. and L. Narayanan,. 2000. Combining ability studies in sunflower (Helianthus annuus L.). Crop Research 20 (3): 457-462.

Badwal, S. S., R. K. Raheja, K. L. Ahuja and B. S. Bawa. 1993. Path analysis of oil yield in sunflower $(H$. annuus L.) hybrids. Indian Journal of Genetics 53: 387-390.

Dağüstü, N. 2002. Correlations and path coefficient analysis of seed yield components in sunflower (Helianthus annuus L.). Turkish Journal of Field Crops 7(1): 5-19.

Dušanic, N., V. Miklic, J. Joksimovic and J. Atlagic. 2004. Path coefficient analysis of some yield components of sunflower. Proceeding of $16^{\text {th }}$ International Sunflower Conference II: 531- 537. Fargo, ND, USA.

Farrokhi, I., A. Khodabandeh, M. and M. Gaffari. 2008 Studies on general and specific combining ability in sunflower. Proceeding of $17^{\text {th }}$ International Sunflower Conference 561-565. Cordoba, Spain.

Gontcharov, S. and M. Zaharova. 2008. Vegetation period of hybrid sunflower productivity in breeding for earliness. Proceeding of $17^{\text {th }}$ International Sunflower Conference 531-533. Cordoba, Spain,

Hladni, N., D. Škoric., M. K. Balalic, M. Ivanovic, Z. Sakac and D. Jovanovic. 2004. Correlation of yield components and seed yield per plant in sunflower (Helianthus annuus L.). Proceeding of $16^{\text {th }}$ International Sunflower Conference II: 491-496. Fargo, North Dakota, USA

Hladni, N., D. Skoric, M. K. Balalic, M. Ivanovic, Z. Sakac and D. Jovanovic. 2006. Combining ability for oil content and its correlations with other yield components in sunflower (Helianthus annuus L.), Helia 29 (44): 101110
Hladni, N., S. Jocic, V. Milkic, M. K. Balalic and D. Skoric, 2008. Gene effects and combining abilities of sunflower morhophysiological traits. Proceeding of $17^{\text {th }}$ International Sunflower Conference. Cordoba, Spain, 545-550.

Joksimovic J, J. Atlagic, D. Jovanovic, R. Marinkovic, N. Dusanic and V. Miklic. 2004. Path Coeffıcient Analysis of some Head and Seed Characteristics in Sunflower. Proceeding of $16^{\text {th }}$ International Sunflower Conference. 525-529. August 29-September 2. Fargo, ND, USA.

Kaya, Y. and I. K. Atakisi. 2003. Path and correlation analysis in different yield characters in sunflower (Helianthus annuus L.). Anadolu Journal 13: 31-45.

Kaya, Y. and I. K. Atakisi. 2004. Combining ability analysis in some yield characters of sunflower (Helianthus annuus L.). Helia 27: 41: 75-84

Kaya, Y. 2005. Determining combining ability in sunflower (Helianthus annuus L.). Turkish Journal of Agriculture and Forestry 243-250.

Kaya, Y., G. Evci, S. Durak, V. Pekcan ve T. Gücer. 2005a. Yağlık ayçiçeğinde verim ilişkileri. Türkiye 6. Tarla Bitkileri Kongresi 619-623. 5-9 Eylül, Antalya.

Kaya, Y., G. Evci, S. Durak, V. Pekcan ve T. Gücer. 2005b. Ayçiçeğinde Tane Doldurma Süresinin Tane Verimi ve Diğer Önemli Verim Öğelerine Etkisi. Türkiye 6. Tarla Bitkileri Kongresi 1-6. 5-9 Eylül, Antalya.

Kaya, Y., G. Evci, V. Pekcan T. Gücer ve S. Durak. 2006. Farklı çevre koşullarında ayçiçeğinde (Helianthus annuus L.) tane verimi ve diğer verim öğeleri arasındaki ilişkilerin belirlenmesi. Trakya Üniversitesi Fen Bilimleri Dergisi 7(1): 37-44.

Kaya Y., G. Evci, S. Durak, V. Pekcan ve T. Gücer. 2007a. Determining the relationships between yield and yield attributes in sunflower. Turkish. Journal of Agricultural and Forestry 31: 237-244.

Kaya, Y, G. Evci, S. Durak, V. Pekcan, T. Gücer ve M. İ. Yılmaz. 2007b. Ayçiçeğinde (Helianthus annuus L) tane veriminin oluşumunda rol oynayan önemli verim öğelerinin katkı oranlarının belirlenmesi. Anadolu 12(2): $1-20$.

Kaya, Y., G. Evci, , V. Pekcan, T. Gucer, S. Durak and I. M. Yilmaz. 2008a. The Path Analysis of yield traits in sunflower (Helianthus annuus L). Latvian Journal of Agronomy 72-77.

Kaya, Y., V. Kaya, G. Evci, İ. Şahin and M. Üstün Kaya. 2008b. Oil type sunflower production in Turkey. Proc. $17^{\text {th }}$ International Sunflower Conference 2: 797-802. Cordoba, Spain. June 8-12. International Sunflower Association. 
Marinković R., D. Škorić, B. Dozet and D. Jovanović. 2000 Line $x$ tester analysis of the combinig ability in sunflower. Proceeding of the $15^{\text {th }}$ International Sunflower Conference. Tome II, E: $30-35$. Toulouse, France.

Miller, J. F. and G. N. Fick. 1997. Sunflower genetics. p. 441495. In: A.A. Schneiter (ed.) Sunflower Technology and Production. Agronomy Monograms 35. ASA. CSSA and SSSA. Madison, WI, USA.

Parameswari, C., V. Muralidharan, B. Subbalakshmi and N. Manivannam. 2004. Genetic analysis yield and important traits in sunflower (Helianthus annuus L.) hybrids. Journal of Oil Seed Research 21(1): 168-170.

Rondanini, D.P., R. Savin and A. Hall. 2007. Estimation of physiological maturity in sunflower as a function of fruit water concentration. European Journal Agronomy 26: 295-309.
Škorić, D., S. Jocić and I. Molnar. 2000. General (GCA) and specific (SCA) combining abilities in sunflower. Proceeding of the $15^{\text {th }}$ International Sunflower Conference, Tome II, E: 23-30. Toulouse, France.

\section{İletişim Adresi:}

\section{Yalçın KAYA}

Trakya Tarımsal Araştırma Enstitüsü

PK: 16, 22100, Edirne, Türkiye

Tel: 284-2358182

Faks: 284-2358210

E-posta: yalcinkaya@ttae.gov.tr 